\title{
Classification of Wedding Entertainment Music in Social Context in Surakarta
}

\begin{abstract}
Resmitra Wisnu Wardhana ${ }^{1}$, Susanto ${ }^{2}$ and Warto $^{3}$
$\{\underline{1}$ resmitrawisnu92@gmail.com $\}$

1,2,3 Cultural Studies, Graduate Program, Universitas Sebelas Maret Surakarta, Indonesia Abstract The marriage support service business is developing and interesting to study. This paper aims to observe the music entertainment services in a wedding reception. The purpose is to classify music entertainment performed at a wedding party, which is categorized into several types, namely location, music groups, genres, and musical instruments. The research process also considers the socioeconomic context in terms of both the environment and the concept of wedding party to build a conceptual framework of art sociology through a qualitative descriptive approach. The data collection used survey which was divided into four major reception venues, namely: (1) hotel (2) building (3) ndaleman (4) house, and interview at the reception spot. The results obtained were ten study locations classified into four tables according to the major locations used. From the results of these classifications, several conclusions can be drawn, such as the location, relationships, economy, tastes, education, family and neighborhood to be the factors that influence the selection of music as entertainment at a wedding reception.
\end{abstract}

Keywords: Music, Wedding Reception, Social Art

\section{Introduction}

Music entertainment is mushrooming in various types of events, both in the formal and informal ones. This is the reason why people increasingly demand more entertainment even at sacred events, such as the Indigenous Marriage ceremony. Most Javanese people still believe that if they do not carry such a ceremony, they will be negatively affected, thus, a ceremony is always carried out seriously and with full confidence [1]. According to the history, music at a wedding is not a new thing. Gamelan music that has been played since Mataram Kingdom era for pahargyan temanten. The very first time gamelan was used to accompany Javanese wedding ceremony is unknown, however, with the long history of Javanese gamelan, playing gamelan in a wedding ceremony is a quite good choice [2].

In this modern era, art is not only an expression of oneself, but also the artist's and the audience's social background portrayal. As to why every wedding ceremony demands art performance is hugely influenced by social factors. The presence of gamelan instruments along with its players who perform song of pahargyan temanten is a symbol of proud social status [1]. It relates to this research, where social status influences the type of musical entertainment chosen for a wedding reception.

In its development, wedding party has undergone many changes in its event arrangement, food, decoration, clothing, and entertainment. According to Hanners (in Sztompka, 1994), this is a factor of global homogenization. Local culture which initially used local music has now been intruded by foreign cultures and it might extend to distant areas [3]. Nanang Martono in 
the Sociology of Social Change (2012:105) said that the whole world will plagiarize each other's lifestyle, consumption patterns, values and norms, and the ideas and beliefs of Western society[4]. In this condition, the uniqueness of local culture (indigenous) will disappear because of the dominance of Western culture [4]. The example can be seen in wedding receptions that carry the concept of garden party and standing party. In those concepts, the entertainment performed might not be Javanese music or campursari, but a band with Western style and music.

Although many are fond of modern concept, there are still some who hold Javanese tradition. They believe that every traditional ceremony, especially marriage, is a form of gratitude that must be shared by involving other people as supporters to achieve social value. According to Notonegoro in Pamungkas (2018:5)[5], social values can be divided into; (1) material value, (2) vital value, (3) spiritual value which is further divided into; (3.1) the value of truth, (3.2) the value of beauty, (3.3) moral value, (3.4) religious value. Therefore, the villagers believe that each individual must perform the ceremony at least once in his or her lifetime. This is where the portion of local wisdom appears dominant in wedding reception with Javanese traditional concepts.

This research will be limited to wedding receptions that take place in the city of Solo and its surroundings. There is no doubt that Solo has been being a cultural city since a long time ago. In addition, the cultural center of Mataram Kingdom is also from this city. This fact will surely give a unique impression on each of the ceremonial celebrations, especially weddings. Globalization is not only a matter of economics, but also the problem of cultural significance [6]. Solo and its surroundings have the potential for socioeconomic significant inequality seen from its ability to hold a wedding reception. There has not been any research previously that discusses the classification of wedding entertainment music, especially in Solo. Therefore, the researchers are interested in classifying wedding music into several types, groups, songs, genres, and musical instruments based on the social context of location and wedding concept.

\section{Research Method}

The data collection was carried out by several survey methods, including observation and interviews. The observation was done by visiting the location of ten wedding receptions from April 2018 to August 2019. In the process, researcher did not only act as observers, but also the music artists itself several times. Observation sites were in several types of public places including buildings, hotels, hall, Ndaleman (a house used to be occupied by the royal members), and houses in Solo and its surroundings. Open interviews were also conducted with the reception guests, the married couples, and their families, depending on the conditions and situation of the field. This interview aims to explore further data regarding the choice of song, music type, musical conduct, and the social condition of the bride and groom.

The data analysis was carried out using qualitative descriptive analysis, by reducing and triangulating data on the results of observations, strengthened by interviews with several respondents at the reception site. The socioeconomic data extracted were also obtained from the ability to hold a reception, starting from the location, catering, decoration, fashion, and makeup. Kirk and Miller in Isono (2013)[7], explained that qualitative research as a particular tradition in fundamental social research depends on human observation in its own area and dealing with people in its discussion and terminology. The data obtained in one reception was being compared to the other receptions to get results that answer the research question. 


\section{Results And Discussion}

Through data collection and library studies, it can be argued that there has never been any research on the choice of wedding entertainment music. M. Jazuli (2014) explains that sociology of art discusses art products through its sustainability, influence or relation, and existing art activities[8]. It is closely related to this research, that the art of music in a wedding party is a product sold by artists to show the social abilities of the audience. Almost the same as Jazuli, Fuente (2007) tried to explain that the 'new sociology of art' also seems confident enough to begin dialogue with other disciplines, such as art history and cultural studies, if and when these discourses share the assumption that art is a social construct, and that its production and consumption are thoroughly social in character[9]. In his book, Jazuli also distinguishes four functions of art in society, namely ceremonial, entertainment, spectacle, and educational media [8]. Thus the function of music entertainment in marriage includes three elements, namely ceremony, entertainment, and spectacle.

"Music for Weddings" an online article by Rizky in 2017[10] and "Music at Parties Makes Events More Life" by Dhaneswari in 2018 [11] are useful articles that provide an overview of trending musical entertainment recommended for wedding reception. Both articles emphasize how to build a good atmosphere that suits reception theme so that it remains on the right track. Based on the articles above, there are several important points in choosing music for a wedding: (1) suit the concept or theme of the wedding party (2) set the mood of the event (3) pay attention to song lyrics. The three points above provide at least a description of the classification in this study, but it will be analyzed further considering the social conditions in the reception. The following table presents the results of the research data.

\subsection{Hotel Receptions}

\begin{tabular}{|c|c|c|c|}
\hline $\begin{array}{c}\text { Date, Location } \\
\text { and Group }\end{array}$ & Genre and Songs & Format and Instruments & Concepts \\
\hline $14 / 04 / 18$ & Pop Indonesia and Western, & Semi Acoustics, & Modern \\
\hline Hotel Sunan. & Traditional arrangement, Dangdut & 1 split bass keyboard, 1 guitar, & National \\
\hline Onny \& & and Melayu, Campursari, Nostalgia & 1 electric drum, 1 male & \\
\hline Friend's feat & songs & vocalist, 1 female vocalist. & \\
\hline Rosmeiga. & & & \\
\hline $21 / 10 / 18$ & Pop Alternative & Acoustic Band & Javanese \\
\hline Hotel Dana. & Pop Indonesia and Western, & 1 guitar, 1 split bass keyboard, & \\
\hline Artcoustic. & Nostalgia songs & $\begin{array}{l}1 \text { electric drum, } 1 \text { male } \\
\text { vocalist, } 1 \text { female vocalist. }\end{array}$ & \\
\hline
\end{tabular}

Based on the observations at the Sunan Hotel, the genre of music presented is quite common and very diverse. It is because the concept is Modern National marriage where the bride and groom come from two different customs namely Batak and Javanese. Thus, the songs performed were also more diverse both in terms of the origin and genre. At that time, the atmosphere was very pleasant because MC Nicko Candra was very communicative and able to work with the musicians. Thus, Onny \& Friend's feat Rosmeiga looked experienced and was able to bring a very cheerful wedding atmosphere, making a hotel venue suitable for the entertainment performed. The second venue is located in the heart of Solo, Jalan Slamet Riyadi, which makes it very easy to find. The hotel is also very often used as a wedding venue. Because both of the couple's parents came from Solo, the concept used was Javanese along with its sacred procession. However, the entertainment presented was an acoustic band. Both of them run independently and do not interfere with each other. It began with the 
Javanese traditional procession from panggih (meet up) to sungkeman (asking for permission by kissing one's hands), followed by entertainment and eating. The music played was more youthful or up to date because the bride has a background in modern design art. The music group who performed at this reception was Artcoustic, a relatively famous group in Solo because they often perform at cafes, restaurants, and hotels.

\subsection{Building Receptions}

\begin{tabular}{|c|c|c|c|}
\hline $\begin{array}{l}\text { Date, Location and } \\
\text { Group }\end{array}$ & Genre and Songs & Format and Instruments & Concepts \\
\hline $15 / 04 / 18$ & Pop Indonesia, Islamic & Solo Organ & Javanese \\
\hline $\begin{array}{l}\text { Langen Parikrama } \\
\text { Building, Gading. } \\
\text { Rizky Entertainment } \\
\text { feat Rosmeiga. }\end{array}$ & $\begin{array}{l}\text { Pop, Dangdut, } \\
\text { Traditional } \\
\text { arrangement. }\end{array}$ & $\begin{array}{l}1 \text { keyboard, } 1 \text { male vocalist, } 1 \\
\text { female vocalist. }\end{array}$ & Islamic \\
\hline $21 / 04 / 18$ & Alternative Pop, & Acoustic Band & National \\
\hline Graha Waris Sejahtera & Western Pop, & 1 Guitar, 1 keyboard split bass, 1 & Modern \\
\hline Building, Kota Barat. & Indonesian Pop, & electric drum, 1 saxophone, 1 & Chinese \\
\hline A \& Friend's. & Christian Gospel & male vocalist, 1 female vocalist. & \\
\hline $25 / 01 / 19$ & Western Pop, & Full band \& Mini Orchestra & Javanese \\
\hline Graha Saba Buana & Indonesian Pop (new & 1 drum, 1 keyboard, 1 guitar, 1 & Modern \\
\hline Building. & and old) & bass, 1 saxo, 2 violin, 1 viola, 1 & \\
\hline Mixolydian feat Ardian & & cello, 1 male vocalist, 1 female & \\
\hline Mini Orchestra \& Voca & & vocalist. & \\
\hline Erudita choir. & & & \\
\hline
\end{tabular}

The first location was in Gading, Surakarta, or often called the Pegadaian Building. This location is often used for weddings, but the rental cost is targeted to the middle to lower economy. This is in accordance with the entertainment music performed where the bride and groom chose a simple Single Organ group. The songs performed were also easy listening and made in Indonesia. The concept used was Javanese Islam, proven by the traditional songs with Islamic nuances being played. The traditional wedding procession also continued at the beginning of the reception using Javanese Gendhing accompaniment.

The second location is in the center of the city, and makes it a favorite option to hold reception. The music group invited was A \& Friend's who is currently the best-selling band in Solo. This is in accordance with the family of the bride and groom who seemed to come from middle to upper social class. The bride and groom wanted to represent their status through the performed music. The concept presented was National Modern Chinese, as seen in the procession of pouring Xuan $\mathrm{Si}$ or a laver of love coming from Chinese customs. The music genre played are mostly interesting and new pop. The professionalism of the band players was proven by their ability to collaborate with the MC, so the event was quite well organized.

The last location observed was Graha Saba Buana, a building familiar to Solo residents because of its strategic and representative location for all events and meetings. This time, the wedding procession was quite interesting and different from the others because the concept was Javanese Modern and there was a touch of Wedding Musical. The bride's background was a singer and make up artist (MUA). Besides, she was also active in UNS Voca Erudita choir. The procession emphasized the music performance as evidenced by many fellow singers performed at this reception. The stage for musicians was arranged large enough in the middle of the building to fit the music personnel and choir groups. As the main band whose popularity was second only to A \& Friend's, Mixolydian performed very well in collaboration with Ardian Dika's mini orchestra, as well as the Voca Erudita choir. 
3.3 Ndaleman Receptions

\begin{tabular}{|c|c|c|c|}
\hline $\begin{array}{l}\text { Date, Location and } \\
\text { Group }\end{array}$ & Genre and Songs & $\begin{array}{l}\text { Format and } \\
\text { Instruments }\end{array}$ & Concepts \\
\hline $\begin{array}{l}\text { 01/05/18 } \\
\text { Ndalem Subiyarsan, } \\
\text { Baturan, Colomadu. } \\
\text { A \& Friend's. }\end{array}$ & $\begin{array}{l}\text { Western Pop, Indonesian Pop, } \\
\text { Christian Gospel }\end{array}$ & $\begin{array}{l}\text { Acoustic Band } \\
1 \text { Guitar, } 1 \text { keyboard split } \\
\text { bass, } 1 \text { electric drum, } 1 \\
\text { male vocalist, female } \\
\text { vocalist }\end{array}$ & $\begin{array}{l}\text { Modern, Semi } \\
\text { Outdoor, } \\
\text { Standing Party }\end{array}$ \\
\hline $\begin{array}{l}04 / 08 / 19 \\
\text { Ndalem } \\
\text { Purwohamijayan, } \\
\text { Kraton Kasunanan. } \\
\text { Keroncong I.B.L.I.S. } \\
\text { (Indonesia Bersama } \\
\text { Leluhur Indonesia } \\
\text { Sukses) }\end{array}$ & $\begin{array}{l}\text { Pop Keroncong, Keroncong } \\
\text { Nostalgia Song, Campursari } \\
\text { Keroncong, Dangdut } \\
\text { Keroncong, Christian Gospel } \\
\text { Keroncong }\end{array}$ & $\begin{array}{l}\text { Complete Keroncong } \\
1 \text { male vocal, } 1 \text { guitar + } \\
\text { backing vocal, } 1 \text { violin, } 1 \\
\text { flute, } 1 \text { bass, } 1 \text { cello, } 1 \\
\text { cak, } 1 \text { cuk }\end{array}$ & $\begin{array}{l}\text { Javanese } \\
\text { National }\end{array}$ \\
\hline
\end{tabular}

The first location is a less popular wedding venue that looks interesting because of the semi-outdoor building concept. The band that peformed was A \& Friend's. Unlike in the previous discussion where the reason to invite this band was because of economy factor, the couple in this section invited the band because they were friends at Church of the A \& Friend's band manager who likes pop music. This can be seen from the closeness of invited guests with several band members. The socioeconomic background of the married couple that comes from middle-class families, can be seen from the selection of a small and less popular location, in addition to its simple-looking decoration. However, the concept was quite interesting because of the semi outdoor standing party, the aisle stage was inside of the pendhopo, while the music stage was on the lawn along with the food stands. Besides Western and Indonesian Pop, Christian religious songs are requested by the bride and groom. The situation is very relaxed because of the small location, so the interaction between personnel and invited guests was very close, as evidenced that several times there are guests who asked to sing.

The second location is in contrast to the previous location, the area is located behind the Kraton Kasunanan Surakarta and it actually belonged to the royal family. The music group invited was Keroncong IBLIS, an unfamiliar and unique group for a wedding performance. However, the genre and the song played turned out to be very interesting and was able to keep up with the current trend. The reason the bride invited this group was because the groom liked Keroncong music and some of the personnel are their Church friends. In terms of background, the bride and groom's families come from the lower middle class, as seen from the choice of venue location, as well as the decoration and dishes served. However, the music played a very good role in Ngunduh Mantu reception. The interaction of personnel with the guests was built very well because in addition to presenting the original music genre of Solo, humor and theatrical tones were also occasionally tucked in by the vocalist.

\subsection{House Receptions}

\begin{tabular}{llll}
\hline $\begin{array}{c}\text { Date, Location } \\
\text { and Group }\end{array}$ & Genre and Songs & Format and Instruments & Concepts \\
\hline $07 / 05 / 20$ & Campursari, Dangdut, & Complete Campursari & National \\
Temuireng, & Javanese Folk Song, & 2 keyboards, 1 guitar, 1 bass, 1 drum + & Java \\
Tegalgede, & Nostalgia Song & $\begin{array}{l}\text { ketipung, 2 kendang ciblon, 1 saron } \\
\text { demung, 2 saron, 1 gong, 1 folk male }\end{array}$ \\
Karanganyar. & & singer, 5 Javanese folk female singers, 1 & \\
O.M. Campursari & & &
\end{tabular}




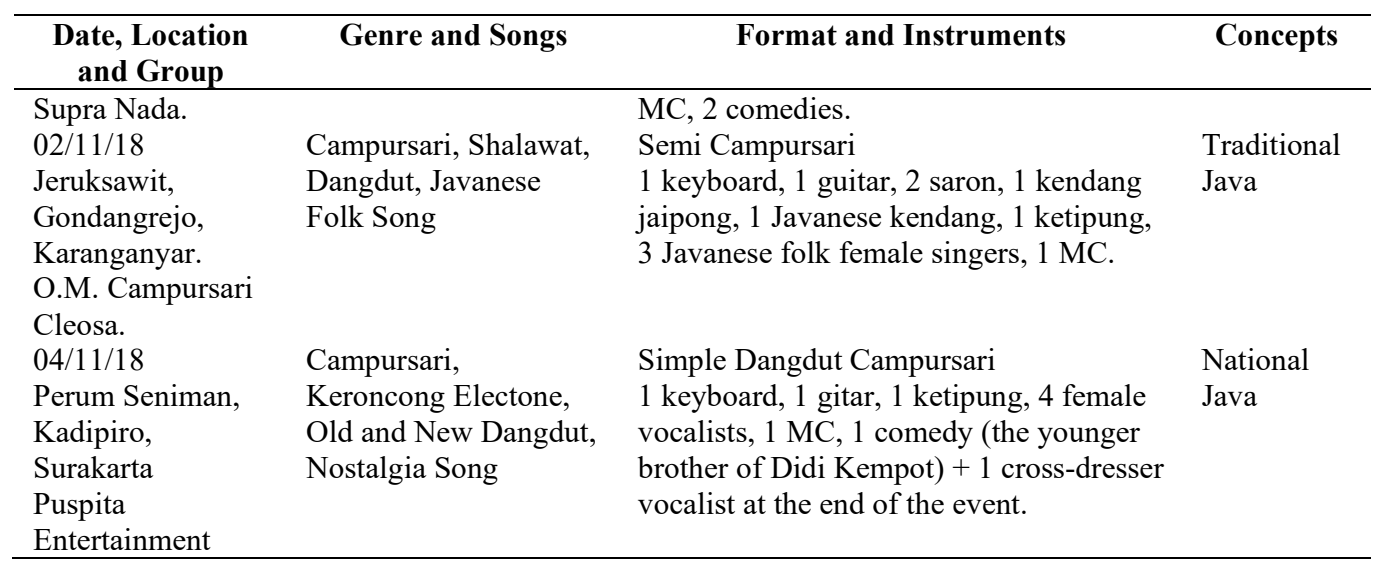

This time, the observation was carried out at the bridegroom's house. The first location was in Temuireng, Tegalgede, Karanganyar, quite far from Solo. The reason for choosing this place is because the bride and groom are friends of researchers who were from high school to college studied in Solo. The location used for Ngunduh Mantu was the groom's house, while the bride's reception was at Graha Waris Building, Solo. The band that performed was Campursari Supra Nada Malay Orchestra, whose performance had a very complete instrument. The educational background of the bride and groom who came from SMK 8 Surakarta and the Surakarta Indonesian Art Institute encouraged a complete performance, not only the music but also comedy show. The bride herself has an educational background in dancing, so it is no wonder that both of them agreed to represent their abilities through the entertainment performed. The genre of music played also adjusted the surrounding community environment that is still fairly middle to lower. Supra Nada music group is fairly well known in Karanganyar, so many guests appreciated their performance at this wedding reception.

The second location is still in Karanganyar, but this time, it is in Jeruksawit, bordering with Mojosongo or North Solo. This area is developing due to the large number of houses being built, but the majority of the people are still traditional. The group performed was the Campursari Cleosa Malay Orchestra, a quite famous group in North Solo but with less complete instruments than Supra Nada. The music genre played almost the same types with the previous location, but there was Shalawatan because their Islamic culture is quite strong, as evidenced by the presence of several mosques around the location. The bride's family has a business in the trading recyclable trashes and the making of karak food. Thus, socially, they are a quite respected family. According to local residents, not all residents were able to rent a complete Campursari group for up to two days in a row, but because the bride's family was seen as quite capable, the local residents understood it. Additionally, the bride is an only child, so the wedding reception was made quite lively by inviting the Campursari group.

The third location is close to the home of Dalang Ki Purbo Asmoro. This time, the groups performing were Campursari and Dangdut ringkes Puspita Entertainment. The group was formed by Puspita, a well-known dangdut and campursari vocalist in Solo. The bride is a relative of Puspita, from the same father but different from mother. The bride's father is also a well-known dangdut singer in the 1980s to 1990s. This passed down to his children who mostly aspire to be music artists. The parents' decision in organizing their children's wedding reception is the result of conformity adaptation patterns to the culture around them [12](Permatasari, 2017). The atmosphere of the reception was very interesting because the relations of the artists were so strong, so there were a number of guest stars present who 
contributed to the songs and jokes. The choice of location alone is actually sufficient to represent the bride and groom so that the entertainment performed is also quite complete and interesting [14]. The music genre played was dominated by Dangdut and Keroncong Electone which were also favored by the local residents because most of them were also artists.

\section{Conclusion}

The first sub-topic is reception at Hotel. The example is the reception at Hotel Sunan, the songs played were traditional, they were rearranged so that they sounded fresher for the guests. Likewise is the reception at Dana Hotel. Although following the parents is the custom, the modern atmosphere was quite evident, as seen from the up to date genre and songs being performed. A traditional Javanese wedding procession accompanied by acoustic band is actually quite common in Solo. Thus, in both locations the bride and groom both want to represent their social status, starting from their hometowns', quality, and their modernity.

Next is building as a reception venue. Venue and social background influence each other in determining music groups as entertainment. In this sub discussion, A \& Friend's as the number one band in Solo tended to be chosen by brides who come from the middle to upper class society even though the location used is not too popular. In contrast to Rosmeiga, the best-selling single organist in Solo is willing to collaborate with a newcomer Rizky Entertainment in a location that is not too popular. The final one is Mixolydian, a famous wedding band in Solo. Quite similar to A \& Friend's, the clients of this group are also middle to upper class people because their performance fee is known to be high in Solo. Thus, the numerous buildings in Solo that vary in rental fee and popularity are not always comparable to the groups invited as there is always a socioeconomic background of the bridegroom's family.

The third sub-topic is Ndaleman. First, A \& Friend's did not only accept jobs in luxury locations and from the middle to upper class, but also agreed to play in a small and simple location considering their relations with the couple and fee agreements. Secondly, Keroncong is entertainment music that is rarely performed at weddings, but this group shows its existence by adapting genres and songs that follow today's trends. Both of these groups have different genres. Each has a different audience market, so the location has no effect on the type of entertainment displayed because in this finding, there is an element of taste and relations between the music group and the married couple.

The last sub-topic is house as a reception venue. Educational background, family, and environment affect the music group choice. For example, in the first location, the couple invited the campursari group because the bride and groom were from the Art Institute and their parents were also artists. Feldman in Ranelis (2014:104) mentions that art life continues to satisfy: (1) individual needs for personal expression, (2) social needs for display, celebration, and communication purposes[13]. This is in line with the selection of campursari to represent the couple's personal expression as an artist as well as strengthening the social needs for celebrations and communicating happiness. Similarly, in the second location, the traditional environment affected the choice of campursari and the neighborhood could understand the families' ability to rent campursari at high cost. The third location is also similar where the bridegroom's parents background was dangdut artist, so the entertainment displayed was also dangdut and many artists came to perform. The choice of location in Perum Seniman allowed the neighborhood to enjoy performance. 


\section{References}

[1] Waridi and B. Murtiyoso, Seni Pertunjukan Indonesia: Menimbang Pendekatan Emik Nusantara. Surakarta: The Ford Foundation \& Program Pendidikan Pascasarjana STSI Surakarta, 2005.

[2] O. M. Syah, "Transformasi Alat Musik Pahargyan Temanten Dari Gamelan Jawa Ke Musik Campursari," ISI Surakarta, 2014.

[3] P. Sztompka, The Sociology of Social Change. UK: Blacwell Publishers, 1994.

[4] N. Martono, Sosiologi Perubahan Sosial. Jakarta: PT Rajagrafindo Persada, 2012.

[5] Pamungkas, I. Galih, S. Aesijah, and Sunarto., "Kesenian Burok Prasasti Di Desa Bojongsari Kecamatan Losari Kabupaten Brebes (Kajian Fungsi Dan Nilai Sosial)," J. Seni Musik, vol. 7, no. 1, pp. 1-8, 2018.

[6] C. Barker, Cultural Studies, Teori \& Praktik. Bantul: Kreasi Wacana, 2016.

[7] M. Isono, "Bentuk Pertunjukan Musik Kasidah Modern Al-Azhar di Desa Tumbrep Kecamatan Bandar Kabupaten Batang," J. Seni Musik, vol. 2, no. 1, 2013.

[8] M. Jazuli, Sosiologi Seni: Pengantar dan Model Studi Seni, 2nd ed. Yogyakarta: Graha Ilmu, 2014.

[9] de La Fuente, "The 'New Sociology of Art': Putting Art Back into Social Science Approaches to the Arts," Cult. Sociol., vol. 1, no. 3, pp. 409-425, 2007.

[10] Rizky, "Music for Weddings," Icubic, 2017. [Online]. Available: http://icubic.co.id/demo/tbd/memilih-musik-untuk-pesta-pernikahan/.

[11] D. Tiara, "Music at Parties Makes Events More Life," Suara Merdeka, 2018. [Online]. Available: http://www.suaramerdeka.com/smcetak/detail/28680/Musik-dalam-Pesta-MembuatAcara-Lebih-Bernyawa. [Accessed: 17-Aug-2019].

[12] Permatasari, A. Fitria, and M. Wijaya, "Perubahan Perilaku Masyarakat Jawa dalam Penyelenggaraan Resepsi Pernikahan di Kota Surakarta,” J. Anal. Sosiol., vol. 6, no. 1, pp. 6581, 2017.

[13] Ranelis, "Seni Kerajinan Bordir Hj. Rosma: Fungsi Personal dan Fisik, dalam Ekspresi Seni," J. Ilmu Pengetah. dan Karya Seni, vol. 16, no. 1, pp. 98-115, 2014.

[14] B.W. Setyawan and K. Saddhono, "Eret traditional ceremony as representation of spirit of mutual cooperation among coastal communities". Adv. Sci. Let. vol. 23 no.10, pp 9991-9992, 2017

[15] K. Saddhono, "Cultural and Social Change of Foreign Students in Indonesia: The Influence of Javanese Culture in Teaching Indonesian to Speakers of Other Languages (TISOL)," in IOP Conference Series: Earth and Environmental Science, 2018, vol. 126, no. 1. 